\title{
PENERAPAN MODEL PEMBELAJARAN DENGAN ARAHAN UNTUK MELATIHKAN KETERAMPILAN EKSPERIMEN DAN PENGUASAAN KONSEP MATERI GAYA PADA SISWA KELAS IV SD
}

\author{
Siti Munawaroh \\ Pendidikan Dasar Pascasarjana Universitas Negeri Surabaya \\ email: wawa_dipadrana@yahoo.com
}

\begin{abstract}
Abstrak
Tujuan penelitian ini adalah menerapkan model pembelajaran dengan arahan untuk melatihkan keterampilan eksperimen dan penguasaan konsep materi gaya pada kelas IV SD. Melalui penerapan pembelajaran dengan arahan siswa dilatih untuk melakukan eksperimen tahap demi tahap sesuai dengan langkah-langkah percobaan sehingga siswa mampu melakukan eksperimen sendiri. Dengan melakukan eksperimen secara mandiri, keterampilan eksperimen dan penguasaan konsep siswa dapat meningkat.

Metode penelitian yang digunakan adalah metode eksperimen semu dengan bentuk one group pretest postest. Penelitian ini dilakukan di SD Negeri 1 Garung Kecamatan Garung, Kabupaten Wonosobo, Provinsi Jawa Tengah. Subjek dalam penelitian ini terdiri atas satu kelompok eksperimen yang berjumlah 25 siswa. Kelompok eksperimen adalah kelompok yang diajarkan dengan menerapkan model pembelajaran dengan arahan. Instrumen penelitian yang digunakan adalah lembar observasi dan instrumen tes.

Berdasarkan hasil analisis data menggunakan lembar pengamatan, keterlaksanaan pembelajaran model direct instruction menunjukkan skor rata-rata 3,6 dalam kategori baik, keterampilan eksperimen siswa mencapai $100 \%$ dengan kategori aktivitas tinggi dan penguasaan konsep siswa pada materi gaya meningkat setelah diajarkan dengan menggunakan model pembelajaran dengan arahan dengan rata-rata proporsi 0,88 . Dengan demikian dapat disimpulkan bahwa penerapan model pembelajaran dengan arahan dapat melatihkan keterampilan eksperimen dan penguasaan konsep materi gaya kelas IV SD.
\end{abstract}

Kata Kunci: Model Pembelajaran dengan Arahan, Keterampilan Eksperimen, Penguasaan Konsep, Gaya.

\begin{abstract}
The purpose of this study was applied the Direct Instruction Model to fasilitate experimental skills and to understand Force Concept of $4^{\text {th }}$ grade in Elementary School. Through of this model was used to trained the skills experiment studens step by step in according by the steps of the experiment that students were could to perfomed their own experiments. Experimental activities that independently conducted, the student's experimental skills and concept capabity can increase.

This reseach by using a quasi experimental method with one group pretest posttest. This research tested in SD Negeri 1 Garung District of Garung, Wonosobo, Central Java. The subjects of this study consisted of an experimental group basis in the student 25 in total. The experimental group was a group that laerned with Direct Instruction Models. The research instrument used is the observation sheet and test instruments.

Based on the analysis of data using observation sheets, the teaching learning process used direct instruction model showed average score 3,6 they're categorized into a good result, experimental skills of students reached $100 \%$ with high activity categories and Understand of concepts students on the material force increased after taught using Direct Instruction Model with an average proportion of 0.88 . It could be concluded that the application of direct instruction model can fasilitate experimental skills and Understand Force Concept of $4^{\text {th }}$ grade in Elementary Shcool.
\end{abstract}

\section{PENDAHULUAN}

Dalam keseluruhan proses pendidikan di sekolah, kegiatan belajar merupakan kegiatan yang paling pokok. Belajar adalah suatu proses yang ditandai dengan adanya perubahan pada diri seseorang (Sudjana, 2009:28). Perubahan sebagai hasil proses belajar dapat ditunjukkan dalam berbagai bentuk seperti perubahan pengetahuan, pemahaman, sikap dan tingkah laku, keterampilan, kecakapan dan kemampuan, daya reaksi, daya peneriman, dan aspek lain yang ada pada individu.
Pembelajaran merupakan suatu upaya yang dilakukan pendidik atau guru secara sengaja dengan tujuan menyampaikan ilmu pengetahuan, dengan cara mengorganisasikan dan menciptakan suatu sistem lingkungan belajar dengan berbagai metode sehingga siswa dapat melakukan kegiatan belajar secara optimal (Sugihartono, dkk. 2007:81). Guru diharapkan mengembangkan kapasitas belajar, kompetensi dasar, dan potensi yang dimiliki oleh peserta didik secara penuh.. 
Bidang studi Ilmu Pengetahuan Alam (IPA) merupakan salah satu bidang studi yang diajarkan di lembaga pendidikan sekolah dasar. IPA merupakan bagian dari kehidupan manusia sehingga pembelajaran IPA merupakan interaksi antara peserta didik dengan lingkungan kehidupannya.

Menurut Mulyasa (2007:111) pendidikan IPA diharapkan dapat menjadi wahana bagi siswa untuk mempelajari diri siswa dan alam sekitar, serta prospek dan pengembangan lebih lanjut dalam menerapkannya di dalam kehidupan sehari-hari. Proses pembelajarannya menekankan pada pemberian pengalaman langsung untuk mengembangkan potensi agar mempelajari dan memahami alam sekitar secara ilmiah.

Menurut Kurikulum KTSP 2006, tujuan pembelajaran IPA di kelas menuntut seorang guru untuk tidak sekedar mampu menyampaikan informasi tentang IPA, melainkan juga harus mampu melatih dan mengembangkan keterampilan proses dalam memperoleh pengetahuan dan mengomunikasikan hasilnya. Pembelajaran IPA yang baik adalah bila dilakukan seperti bagaimana IPA ditemukan. IPA adalah karya manusia yang dihasilkan/ditemukan, yaitu lewat metode ilmiah dan menggunakan keterampilan proses IPA (Ibrahim, 2010:3). Mengajarkan keterampilan proses berati memberi kesempatan untuk melakukan IPA dan tidak sekedar memberitahukan IPA.

Menurut Abruscato (1992) dalam Khaerudin dan Sujiono (2005:32) melakukan eksperimen merupakan salah satu keterampilan proses terintegrasi. Djamarah dan Zain (2006:100) mengemukakan eksperimen adalah suatu metode yang siswanya mencoba mempraktikkan suatu proses tersebut, setelah melihat/mengamati apa yang didemonstrasikan oleh seorang demonstran. Ekperimen dapat juga dilakukan untuk membuktikan kebenaran sesuatu, misalnya menguji hipotesis. Agar siswa memiliki keterampilan eksperimen, maka harus dilatih untuk melakukan kegiatan sehubungan dengan keterampilan ekperimen.

Selain mengembangkan keterampilan eksperimen, pembelajaran IPA bertujuan memperoleh bekal pengetahuan konsep. Berdasarkan pernyataan tersebut konsep-konsep dasar diberikan secara benar dan memberikan penekanan pada kegiatan serta pengamatan yang lebih konkrit terhadap sesuatu yang diajarkan. Konsep merupakan kategori yang diberikan kepada stimulus yang ada di lingkungan (Dahar, 2011:62). Belajar konsep merupakan hasil utama pendidikan sehingga konsep merupakan batu pembangun berpikir. Konsep merupakan dasar bagi proses mental yang lebih tinggi untuk merumuskan prinsip dan generalisasi.

Berdasarkan observasi awal yang dilakukan peneliti di kelas IV SD Negeri 1 Garung, diperoleh keterangan bahwa dalam kegiatan pembelajaran guru lebih sering menggunakan metode ceramah tanpa kegiatan ekperimen ataupun demonstrasi dalam membahas materi-materi IPA. Menurut Jufri (2013:157) guru masih banyak yang membelajarkan IPA hanya dengan metode ceramah dan tugas-tugas membaca sebagai pola pembelajaran pokok. Pengalaman dan kegiatan belajar kurang diarahkan bagaimana cara mengkonstruksi ide-ide atau gagasan ilmiah yang baru melalui proses penemuan ilmiah. Akibatnya, hasil belajar IPA pun masih belum mencapai ketuntasan yang ditetapkan sekolah sebesar 72 .

Persediaan alat di sekolah juga berpengaruh terhadap hasil belajar siswa. Secara khusus, anak kelas empat merupakan siswa kelas atas yang umumnya memiliki usia antara 9-10 tahun dan berada pada tahap operasional konkrit. Pada tahap usia ini anak memilki kekhasan antara lain dapat berpikir reversibel atau bolak balik, dapat melakukan pengelompokan dan menentukan urutan, telah mampu melakukan operasi logis tetapi pengalaman yang dipunyai masih terbatas (Maslichah Asy'ari, 2006:42). Anak mengembangkan pemikiran secara logis, masih sangat terikat pada fakta-fakta perseptual, artinya anak mampu berfikir logis, tetapi masih terbatas pada objek-objek konkrit, dan mampu melakukan konservasi. Dalam pembelajaran IPA guru jarang menggunakan alat dan melakukan eksperimen. Siswa menjadi kurang tertarik dalam mengikuti pembelajaran IPA karena hanya mendengarkan ceramah yang disampaikan guru. Ketidaktertarikan siswa dalam pembelajaran menyebabkan motivasi siswa dalam belajar kurang dan berdampak pada hasil belajar yang rendah.

Berdasarkan hal di atas, maka peneliti berusaha mencarikan model pembelajaran lain yang lebih efektif untuk meningkatkan aktivitas belajar dan mendukung mengembangkan potensi siswa secara optimal baik dari segi kognitif, afektif maupun psikomotorik. Direct Instruction khusus dirancang untuk mengembangkan belajar siswa tentang belajar prosedural dan pengetahuan deklaratif yang dapat diajarkan dengan pola selangkah demi selangkah (Sugiarto, 2009:32).

Pengetahuan deklaratif (dapat diungkapkan dengan kata-kata) adalah pengetahuan tentang sesuatu, sedangkan pengetahuan prosedural adalah pengetahuan tentang bagaimana melakukan sesuatu (Kardi dan Nur, 2005:4). Hal ini sependapat dengan 
Arends (1997:66) yang mengatakan bahwa "The direct instruction model was specifically designed to promote student learning of prosedural knowledge and declarative knowledge that is well structured and can be taught in a step-by-step fashion."

Lebih lanjut Arends (2012:297) menyatakan bahwa: "Direct instruction is a teacher-centered model that have five steps: establishing set, explanation and/or demonstration, guide practice, feedback, and extended practice. A direct instruction lesson requirs careful orchestration by the teacher and a learning environment that businesslike and task-oriented". Direct Instruction adalah sebuah model yang berpusat pada guru, yang memiliki lima langkah: establishing set, penjelasan dan/atau demonstrasi, latihan terbimbing, umpan balik, dan latihan lanjutan. Sebuah pelajaran dengan model direct instruction membutuhkan orkestrasi yang cermat oleh guru dan lingkungan belajar yang praktis, efisien, dan berorientasi pada tugas.

Proses pembelajaran dengan penerapan model direct instruction yang diusulkan dan ingin digunakan peneliti bertujuan untuk menunjang proses belajar siswa yang berkaitan dengan pengetahuan prosedural dan pengetahuan deklaratif yang terstruktur dengan baik, yang dapat diajarkan dengan pola kegiatan bertahap, selangkah demi selangkah.

Sedangkan metode yang dipilih harus mendasari skenario pembelajaran yang mencoba memfasilitasi terjadinya pengalaman belajar yang dapat mengembangkan kreativitas siswa. Dalam pembelajaran ini metode yang dipilih adalah metode eksperimen.

Siswa akan mempelajari IPA di tingkat yang lebih tinggi dalam waktu singkat sehingga perlu dilatihkan keterampilan eksperimen agar siswa terampil dalam eksperimen. Eksperimen adalah percobaan untuk membuktikan suatu pertanyaan atau hipotesis tertentu (Sagala, 2011:220).

Dalam proses belajar mengajar dengan eksperimen ini siswa diberi kesempatan untuk mengalami sendiri atau melakukan sendiri, mengikuti proses, mengamati suatu objek, menganalisis, membuktikan dan menarik kesimpulan sendiri tentang suatu objek, keadaan atau proses sesuatu. Dengan keterampilan eksperimen tersebut siswa akan lebih mudah dalam memahami konsep-konsep IPA.

Pokok bahasan Gaya merupakan materi yang berhubungan erat dengan kehidupan seharihari maka sangatlah penting materi tersebut dipelajari dengan tuntas. Pokok bahasan Gaya sangat cocok diajarkan dengan menggunakan model direct instruction karena terdapat banyak informasi tentang fakta-fakta dan konsep-konsep yang cocok diajarkan dengan menggunakan pengetahuan deklaratif (pengetahuan yang bisa dideklarasikan biasanya dalam bentuk kata atau singkatnya pengetahuan konseptual), misalnya setiap benda yang dilempar ke angkasa akan jatuh ke bumi karena adanya gaya gravitasi dan membutuhkan pembuktian melalui demonstrasi/eksperimen yang merupakan pengetahuan prosedural (pengetahuan tentang tahapan yang harus dilakukan).

Metode

Desain yang digunakan adalah PreEksperimental Desains yaitu The One Group Pretest-Posttest. Subjek penelitian ini adalah siswa kelas IV SD Negeri 1 Garung tahun pelajaran 2014/2015 yang berjumlah 25 siswa. Terdiri atas 12 siswa laki-laki dan 13 siswa perempuan.

Pada desain ini diberikan pretest sebelum diberikan perlakuan. Dengan demikian hasil perlakuan dapat diketahui lebih akurat karena dapat membandingkan dengan keadaan sebelum diberikan perlakuan. Desain ini dapat digambarkan seperti berikut.

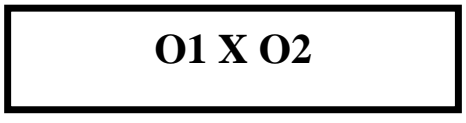

Keterangan:

01: Pretest

O2: Posttest

X:Treatment (Adaptasi dari Sugiyono, 2010:111)

Hasil dan Pembahasan

a. Keterlaksanaan Pembelajaran Model Direct Instruction

Keterlaksanaan model pembelajaran dengan menggunakan model direct instruction, meliputi memotivasi siswa, menjelaskan tujuan pembelajaran, melakukan demonstrasi pengetahuan atau prosedural langkah demi langkah, membimbing siswa melatih pengetahuan atau prosedural langkah demi langkah, mengecek pemahaman siswa dan memberikan umpan balik, memberikan pelatihan lanjutan, menyusun kesimpulan hasil belajar, melakukan refleksi hasil pembelajaran, pengelolaan waktu, siswa antusias dan guru antusias.

Keterlaksanaan RPP pelaksanaan penelitian selengkapnya dapat dilihat pada tabel berikut. 
Tabel 1 Skor Keterlaksanaan RPP Direct Instruction

\begin{tabular}{|c|c|c|c|}
\hline RPP & Pertemuan & $\begin{array}{l}\text { Rata- } \\
\text { rata }\end{array}$ & Reliabilitas \\
\hline \multirow[t]{3}{*}{1} & P1 & 3,3 & \multirow{3}{*}{0,97} \\
\hline & P2 & 3,5 & \\
\hline & $\mathbf{X}$ & 3,4 & \\
\hline \multirow[t]{3}{*}{2} & P1 & 3,7 & \multirow{3}{*}{0,99} \\
\hline & $\mathbf{P 2}$ & 3,6 & \\
\hline & $\mathbf{X}$ & 3,7 & \\
\hline \multirow[t]{3}{*}{3} & P1 & 3,8 & \multirow{3}{*}{0,99} \\
\hline & $\mathbf{P 2}$ & 3,7 & \\
\hline & $\mathbf{X}$ & 3,8 & \\
\hline & erata & 3,6 & \\
\hline
\end{tabular}

Data yang diperoleh menunjukkan bahwa skor rata-rata RPP tiap pertemuan yang dicapai peneliti adalah pertemuan 1 rata-rata 3,4 ; pertemuan 2 rata-rata 3,7 ; pertemuan 3 rata-rata 3,8 dengan reliabilitas pertemuan 10,97 ; pertemuan 2 0,99; dan pertemuan 3 0,99.

Dari RPP pertemuan 1, pertemuan 2, dan pertemuan 3 dapat disimpulkan bahwa untuk keterlaksanaan RPP dalam pembelajaran direct instruction dikategorikan baik.

Walaupun secara keseluruhan keterrlakasaan RPP sudah cukup baik, namun masih terdapat kekurangan. Kekurangan ini terletak pada pengelolaan waktu pembelajaran terutrama pada pertemuan 1. Kemampuan guru dalam menggunakan waktu yang disediakan belum maksimal. Waktu banyak tersita pada fase mendemonstrasikan, memberikan latihan terbimbing, dan memberikan latihan lanjutan. Hal ini disebabkan karena siswa baru pertama kali melakukan pembelajaran dengan metode menggaris bawahi bacaan dan membuat peta konsep. Slavin (2011) menyatakan bahwa jika guru memperkenalkan keterampilan atau konsep baru kepada siswa, mungkin dibutuhkan pembahasan yang lebih panjang. Selain itu fase kedua dari model direct instruction menurut Eggen dan Kauchak (2012:373) merupakan fase yang paling sulit bagi guru karena guru harus memberikan penjelasan agar siswa memahami informasi dan keterampilan yang disampaikan. b. Keterampilan Eksperimen Siswa

Dari hasil analisis data, kemunculan aktivitas eksperimen dalam pembelajaran menggunakan model direct instruction pada pertemuan 2 meliputi merumuskan hipotesis $(16,03 \%)$, menggunakan alat dan bahan percobaan (16,03\%), melakukan kegiatan percobaan/eksperimen (16,03\%), melakukan pengamatan $(16,03 \%)$, mencatat hasil pengamatan $(16,03 \%)$, menyimpulkan data $(16,03 \%)$, mempresentasikan hasil kegiatan $(3,85 \%)$ dengan reliabilitas $100 \%$. Sedangkan pada pertemuan 3 diperoleh data yaitu merumuskan hipotesis $(15,43 \%)$, menggunakan alat dan bahan percobaan $(15,43 \%)$, melakukan kegiatan percobaan/eksperimen (15,43\%), melakukan pengamatan $(15,43 \%)$, mencatat hasil pengamatan $(15,43 \%)$, menyimpulkan data $(15,43 \%)$, mempresentasikan hasil kegiatan $(7,41 \%)$ dengan reliabilitas $100 \%$. Rata-rata presentase aktivitas eksperimen $100 \%$ dengan kategori tinggi.

Kegiatan eksperimen siswa ini terbagi menjadi dua bagian. Bagian pertama siswa melakukan eksperimen dengan bimbingan guru (latihan terbimbing) dan kegiatan eksperimen lanjutan (latihan lanjutan). Hal ini sesuai dengan Joyce dan Weil (2011:423) yang menyatakan bahwa direct instruction terdiri atas penjelasan guru mengenai kosep atau keterampilan serta memberikan peragaan, di lanjutkan dengan melakukan praktik di bawah bimbingan guru, dan mendorong mereka meneruskan ke praktek mandiri (latihan lanjutan). Melalui kegiatan terbimbing dan kegiatan lanjutan, siswa dapat mengerjakan kegiatan eksperimen pada LKS dan mampu menemukan konsep pengaruh gaya terhadap gerak dan bentuk benda.

c.Penguasaan Konsep Siswa

Berdasarkan analisis data terlihat bahwa sebelum perlakuan diberikan, seluruh siswa memperoleh nilai proporsi terendah 0,25 dan nilai proporsi tertinggi 0,70 dengan nilai rata-rata pretest 0,50 . Dari 25 siswa yang mengikuti pretest, semua siswa belum mencapai kriteria ketuntasan $\geq 0,72$. Setelah diberikan perlakuan yaitu dengan model direct instruction pada materi gaya, diperoleh nilai rata-rata postest sebesar 0,88 . Hal ini berarti ada peningkatan perolehan nilai antara pretest dan postest. Proporsi nilai tertinggi diperoleh siswa dalah 1,00 dan nilai terendah adalah 0,55. Dari 25 siswa yang mengikuti postest, terdapat 24 siswa tuntas dan 1 siswa tidak tuntas. Ini berarti kriteria ketuntasan sudah tercapai dengan presentase $96 \%$. 
d. Kendala-kendala dalam Pelaksanaan

Dari keterlaksanaan RPP dijumpai beberapa kendala selama pelaksanaan RPP antara lain:

1. Guru kurang memperhatikan alokasi waktu

2. Siswa masih belum terbiasa membuat peta konsep

3. Siswa masih belum percaya diri ketika guru meminta untuk menyampaikan hasil kerjanya di depan teman-teman sekelasnya ataupun untuk bertanya.

Adapun solusinya adalah:

1. Guru lebih memperhatikan lagi alokasi waktu dalam pengaturan waktu pada pertemuan berikutnya.

2. Guru membimbing siswa dalam membuat peta konsep.

3. Guru memberi motivasi kepada siswa untuk berani tampil di depan teman-temannya tanpa khawatir salah atau benar.

\section{Simpulan}

Simpulan yang dapat diambil berdasarkan data hasil penelitian dan analisis yang telah dilakukan adalah:

1. Keterlaksanaan pembelajaran model direct instruction menunjukkan skor rata-rata 3,6 dalam kategori baik dengan rincian tiap sintaks sebagai berikut: memotivasi siswa dan menjelaskan tujuan pembelajaran 3,7; melakukan demonstrasi pengetahuan atau prosedural langkah demi langkah 3,7; membimbing siswa melatih pengetahuan atau prosedural langkah demi langkah 3,3; mengecek pemahaman siswa dan umpan balik 4; memberikan pelatihan lanjutan 3,5.

2. Keterampilan eksperimen siswa dalam pembelajaran menggunakan model direct instruction termasuk dalam kategori aktivitas tinggi dengan persentase $100 \%$.

3. Penguasaan konsep siswa pada materi gaya meningkat setelah diajarkan dengan menggunakan model direct instruction dengan rata-rata proporsi jawaban benar yang diperoleh siswa 0,88 berkategori tinggi.

4. Kendala utama yang dihadapi pada pembelajaran materi gaya dengan menggunakan model direct instruction adalah siswa belum terbiasa membuat peta konsep sehingga pada pertemuan awal guru membutuhkan waktu lebih lama untuk memberikan latihan bimbingan.
Saran

Berdasarkan simpulan di atas, maka diberikan beberapa saran sebagai berikut:

1. Pembelajaran dengan model direct instructon dapat dijadikan alternatif pembelajaran di SD.

2. Dalam menerapkan model direct instruction, pemodelan merupakan hal yang penting. Untuk itu posisi mengajar perlu diperhatikan agar semua siswa dapat mengamati dan menirukan guru.

3. Dalam melaksanakan model direct instruction, guru hendaknya melakukan kegiatan sesuai dengan sintaks.

4. Kerjasama dan koordinasi yang baik antara guru dan pengamat sangat diperlukan guna mendapatkan persepsi yang sama dalam penelitian.

\section{DAFTAR PUSTAKA}

Arends, R. (1997). Classroom Instruction and Management. New York: Mc Graw- Hill.

Arends, R. (2012). Learning to Teach. New York: Mc Graw- Hill.

Dahar, R. (2011). Teori-teori Belajar dan Pembelajaran. Jakarta: Erlangga.

Djamarah, S dan Zain, A. (2006). Strategi Belajar Mengajar. Jakarta: Rhineka Cipta.

Eggen dan Kauchak. (2012). Strategi dan Model Pembelajaran: Mengajarkan Konten dan Keterampilan Berpikir. Jakarta: PT Indeks.

Jufri, W. (2013). Belajar dan Pembelajaran Sains. Bandung: Pustaka Reka Cipta.

Joyce, B and Weil, M. (2011). Model of Teaching Model-model pengajaran. Yogyakarta: Pustaka Belajar.

Kardi, S dan Nur, M. (2005). Pengajaran Langsung. Surabaya: Unesa University Press.

Khaeruddin dan Sujiono, E. (2005). Pembelajaran Sains (IPA) Berdasarkan Kurikulum Berbasis Kompetensi. Makassar: Badan Penerbit Universitas Negeri Makassar.

Mulyasa, E. (2007). Kurikulum Tingkat Satuan Pendidikan. Bandung: Remaja Rosdakarya Offset. 
Sagala, S. (2011). Konsep dan Makna Pembelajaran. Bandung: Alfabeta.

Slavin, R. (2011). Psikologi Pendidikan Teori dan Praktik Jilid Satu. Jakarta: PT Indeks

Sudjana, N. (2009). Dasar-dasar Proses Belajar Mengajar. Bandung: Sinar Baru Algensindo.

Sugiarto, B. (2009). Mengajar Siswa Belajar Implementasi Guru di Dalam Kelas. Surabaya: Unesa University Press.

Sugihartono, dkk. (2007). Psikologi Pendidikan. Yogyakarta:UNY Pres.
Tim Penyusun Kurikulum SD. 2006. Kurikulum Tingkat Satuan Pendidikan. Jakarta: Depdiknas. 